\title{
Austrostipa (Poaceae) subgenus Lobatae in Western Australia
}

\author{
Alexander R. Williams \\ Western Australian Herbarium, Department of Environment and Conservation \\ Locked Bag 104, Bentley Delivery Centre, Western Australia 6983
}

\begin{abstract}
Until recently, Austrostipa Jacobs \& Everett subgenus Lobatae Jacobs \& Everett was represented in Western Australia by two species, A. juncifolia, which is common in saline areas in the southern Wheatbelt, and the rare A. geoffreyi, which is found only on the margins of three salt lakes in the same region. Two new rare species are here described from calcareous soils on the Swan Coastal Plain in non-saline habitats, hundreds of kilometres from their nearest relatives. Austrostipa jacobsiana is known from a single small population in Perth and a single small population in Bunbury, and A. bronwenae is known from a single small population in the proposed Kemerton Nature Reserve and a small population in Perth. Both new species have declined in population size over the few years since discovery and warrant urgent priority status for conservation. All four Western Australian species in the subgenus are described and illustrated.
\end{abstract}

\section{Introduction}

The spear grasses (Austrostipa spp., formerly Stipa L. spp.) form the largest genus of native perennial grasses in the southwest of Western Australia (W.A.). The genus in W.A. was treated by Gardner (1952) and more recently at the national level by Vickery et al. (1986), Jacobs \& Everett (1996) and Everett et al. (2009). Keys to Australian grasses that include W.A. species of Austrostipa can be found in Simon (1993), Simon \& Sharp (2002) and Everett et al. (2009). Phylogenetic relationships within the stipoid grasses have been discussed by Jacobs et al. (2000, 2007).

Austrostipa subgenus Lobatae occurs across southern Australia, with one species (A. stipoides) also native to New Zealand, the only Austrostipa known to be native outside Australia. According to Jacobs et al. $(2000,2007)$ it is quite remote in its relationships to other groups in Austrostipa, on both genetic and morphological grounds. 
Two new species are here described, A. jacobsiana known only from one small population in Perth and one in Bunbury, and A. bronwenae known only from a small population in the proposed Kemerton Nature Reserve near Harvey and a small population in Perth. Both species are geographically isolated from their nearest morphological relatives, A. juncifolia and A. geoffreyi, by the Darling Range and distances in excess of 300 kilometres, and differ ecologically from them in occupying non-saline habitats.

\section{Materials and Methods}

All specimens within the subgenus in the PERTH herbarium were examined in 2003. A specimen collected by Bronwen Keighery in suburban Perth in December 1995 was the first collection of the subgenus from the Swan Coastal Plain and was given the phrase name Austrostipa juncifolia subsp. Southern River (B.J. Keighery 2160). Further collections at various times from the Perth area were made by the author and Una Bell. Bronwen Keighery identified Muchea Limestone (Keighery \& Keighery 1995) as a potential ecological marker for the taxon and subsequently made new collections, one of which was given the phrase name Austrostipa sp. Harvey (B.J. Keighery GWAL/1), from these sites in the Bunbury and Harvey areas. She also collected fertile type material at the author's request. Cate Tauss subsequently collected this species in suburban Perth.

A character used in this study, but not previously reported in Austrostipa, is the involucel, a structure subtending the basal node and sometimes also the higher nodes of the panicle. According to McCusker (2007) an involucel is "an involucre of bractlets surrounding a secondary inflorescence such as the base of an umbellule." Since the grass panicle is made up of primary and secondary inflorescences (Vegetti \& Anton 2000) this seems to be an appropriate term. Figure 1 illustrates involucels of three

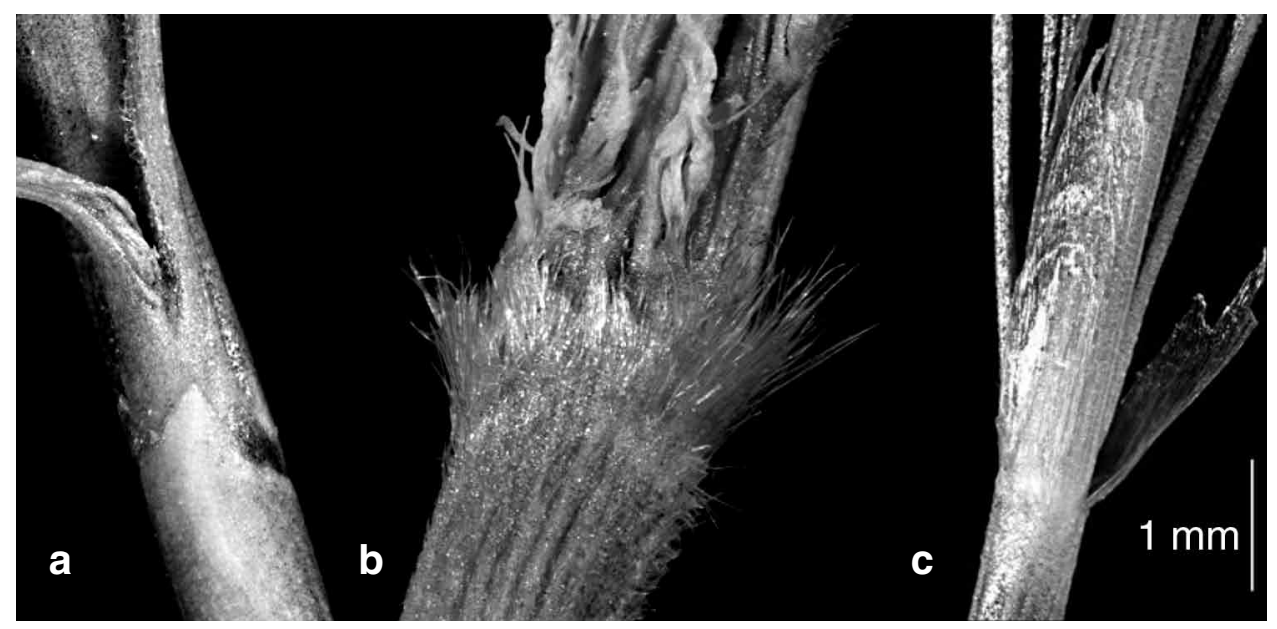

Fig. 1. Involucels subtending panicles in Austrostipa. a, short, glabrous, indurated, stemclasping bract almost surrounding the culm (A. juncifolia, subgenus Lobatae); $\mathbf{b}$, dense ring of hairs completely surrounding the culm (A. hemipogon, subgenus Austrostipa); c, long glabrous membrane completely surrounding the culm (A. trichophylla, subgenus Falcatae). Digital images from: a Royce 6063; b McCallum Webster WA/508; c Bell 480. 
different kinds from three subgenera within the genus. They range from a long, glabrous membrane or short, indurated ridge of tissue, to a ring of hairs or a hairy membrane, and either partially or completely surround the culm; the involucel can also be absent. Three components were required to define the character in these present specimens: the length of the bract, the presence of hairs, and the extent to which it encircled the culm. The involucel appears to be variable within species in some subgenera, but in subgenus Lobatae it is consistent within species.

Panicle size and density varies in a way that required two previously unused characters. Panicle internode length: if necessary, the culm must be excised to make sure the base of the panicle is exposed; sometimes the first node is undeveloped and enclosed within the leaf sheath, so to compensate for this the value used was taken as the average of the first two internodes. Maximum undivided branch length: this is the greatest length of the undivided primary branches at a given node; it is a measure of panicle density.

The PERTH collections of Austrostipa species have expanded considerably in recent years so the descriptions of Austrostipa juncifolia and A. geoffreyi which follow are based upon data published in Vickery et al. (1986) and Everett et al. (2009) modified where necessary to include the PERTH specimen data. All the specimens cited below are held at PERTH.

\section{Taxonomy}

\section{Austrostipa subgenus Lobatae S.W.L.Jacobs \& J.Everett}

Perennial rush-like, tussock-forming grasses with erect, unbranched, glabrous culms and leaves, basal sheaths sometimes with short hairs, innovations arising extravaginally from a short rhizome, without a basal tuft leaf of leaves, nodes $2-4$, exserted, thickened, glabrous. Leaf sheaths tightly clasping the culm. Leaves green at flowering time, stiff and rush-like, arising without interruption from the sheaths, folded or rolled into a terete form that makes them almost indistinguishable from the culms. Collar region largely invisible, with no auricle or angular articulation with the leaf blade. Sheath lobes and ligules glabrous, and often very long. Involucels short and indurated, either glabrous or hairy. Inflorescence exserted; spikelets gaping. Callus weakly bent. Lemma $6.5-13 \mathrm{~mm}$ long, with white, yellow or fulvous hairs over most of the body; coma $0.7-3 \mathrm{~mm}$ long, or obscure; lobes $2,0.3-3 \mathrm{~mm}$ long; awn $2-8 \mathrm{~cm}$ long, twice geniculate. Palea equal to lemma.

The subgenus takes its name from the very long lemma lobes of the type species, Austrostipa juncifolia. Distributions of W.A. species in the subgenus are given in Fig. 2. 


\section{Key to the W.A. species in Austrostipa subgenus Lobatae}

1. Basal leaf sheaths $7-14 \mathrm{~mm}$ wide (in situ); ligule $2.5-12 \mathrm{~mm}$ long, smoothly integrated with the sheath so there are no sheath lobes; lemma lobes $1-3 \mathrm{~mm}$ long; growing around salt lakes or salinised soils in the southern Wheatbelt of Western Australia

2. Upper glumes 9-10 mm long; floret $6.5-9 \mathrm{~mm}$ long; callus $1.1-1.5 \mathrm{~mm}$ long; lemma lobes 1-2.5 mm long; awn 25-50 mm long; anthers penicillate; style glabrous; widespread in Southern Wheatbelt A. juncifolia

2. Upper glumes $12-16 \mathrm{~mm}$ long; floret 9-12 mm long; callus 2-3 mm long; lemma lobes $2.5-3 \mathrm{~mm}$ long; awn 50-80 mm long; anthers not penicillate; style hispid with bristly hairs $0.2-0.4 \mathrm{~mm}$ long; known only from Lakes King, Grace and Chinocup A. geoffreyi

1. Basal leaf sheaths $2-4 \mathrm{~mm}$ wide (in situ); ligule $0.0-1.0(-2) \mathrm{mm}$ long, usually shorter than adjacent sheath lobes; lemma lobes 0.4-1.0 mm long; growing on the Swan Coastal Plain in non-saline calcareous soils

3. Ligule broad between short sheath lobes; involucel a glabrous ridge of indurated tissue not encircling the culm; upper glume 5-nerved in the lower part; lemma hairs white at maturity; anthers not penicillate, $3.2-3.3 \mathrm{~mm}$ long.

A. jacobsiana

3. Ligule narrow to almost absent between long sheath lobes $(2-6 \mathrm{~mm})$; involucel of hairs $0.3-1.3 \mathrm{~mm}$ long that almost encircle the culm; upper glume 3-nerved in the lower part; lemma hairs dark golden brown at maturity; anthers penicillate, $4.2-5 \mathrm{~mm}$ long

A. bronwenae

Austrostipa juncifolia (Hughes) S.W.L.Jacobs \& J.Everett, Telopea 6: 586 (1996). Stipa juncifolia Hughes, Bull. Misc. Inform. 1921: 11 (1921).

Type: Western Australia, Swan River [Colony], Drummond 4th coll. no. 377 (holo:K; iso: CANB236993, photo!).

Perennial grass, 80-100 $\mathrm{cm}$ tall. Leaf sheaths 7-9 $\mathrm{mm}$ wide at the base of the culm, 3-6 $\mathrm{mm}$ wide at the upper nodes. Upper leaf sheaths smooth and glabrous, lower sheaths slightly ribbed and puberulous or pubescent with hairs $0.01-0.2 \mathrm{~mm}$ long. Ligules $2.5-8 \mathrm{~mm}$ long, continuous with the leaf sheath so there are no sheath lobes, sparsely puberulous abaxially. Auricular region unmarked, glabrous or with a few sparse hairs. Leaf blades 33-50 cm long, 1-2 mm wide; blade folded and swollen to create a terete form, abaxial surface not ribbed, glabrous and smooth, adaxial surface strongly ribbed, pubescent with an even covering of erect hairs $0.03-0.6 \mathrm{~mm}$ long. Panicle 25-35 cm long, exserted, contracted, $3.5-8 \mathrm{~cm}$ wide, involucel a glabrous ridge of tissue and a short bract; lowest panicle internode $60-80 \mathrm{~mm}$ long, glabrous; shortest undivided branch 3-13 mm long, longest undivided branch 25-40 $\mathrm{mm}$ long; branches terete, mostly glabrous but with hairs near the axils, $80-100 \mathrm{~mm}$ long overall including glumes; pedicels terete, $0.5-2 \mathrm{~mm}$ long, mostly glabrous but with hairs near the axils; spikelets 8-28 per node, 10-12 mm long. Glumes persistent, subequal, acuminate, glabrous or with sparse longer hairs on body and short denser hairs near the apex, straw-coloured; lower glume 3-nerved, 10-12 mm long; upper glume 3-nerved, 
9-10 mm long. Floret 6.5-9 mm long, without a neck, sericeous with white hairs at maturity, $0.5-0.8 \mathrm{~mm}$ long, increasing in length towards the apex. Lemma lobes 2, 1-2.5 mm long; coma 1.3-3 mm long; callus 1.1-1.5 mm long, sericeous with white hairs $0.1-1.0 \mathrm{~mm}$ long, tip weakly bent. Awn $25-50 \mathrm{~mm}$ long, $0.2-0.25 \mathrm{~mm}$ wide near the base, twice bent, column 10-20 mm long, 5-10 $\mathrm{mm}$ to the first bend, scabrous, with hairs $0.1-0.5 \mathrm{~mm}$ long, bristle triangular, no broader than column, paler than the column, scabrous with hairs $0.1-0.15 \mathrm{~mm}$ long. Palea equal to and almost completely enclosed by lemma, with glabrous margins, pubescent between the dorsal nerves. Lodicules 2 or 3, membranous; abaxial lodicules acute or obtuse, $0.5-1.5 \mathrm{~mm}$ long, $0.3 \mathrm{~mm}$ wide; paleal lodicule acute, $1.5-2 \mathrm{~mm}$ long, $0.2 \mathrm{~mm}$ wide. Anthers 3, 5-6 mm long, penicillate ( 6 penicilli on each locule). Style glabrous. Caryopsis 4.0-4.8 mm long, $1 \mathrm{~mm}$ wide; hilum 3-3.5 mm long, embryo 1.1-1.3 mm long. (Fig. 3)

Distribution and habitat: occurs in the following Western Australian IBRA regions: Coolgardie, Jarrah Forest, Avon Wheatbelt, Mallee and Esperance Plains (Fig. 2). Grows on the margins of salt lakes, in saline or seasonally damp salinised soils.

Phenology: flowers October-November with fruit maturing in November-December.

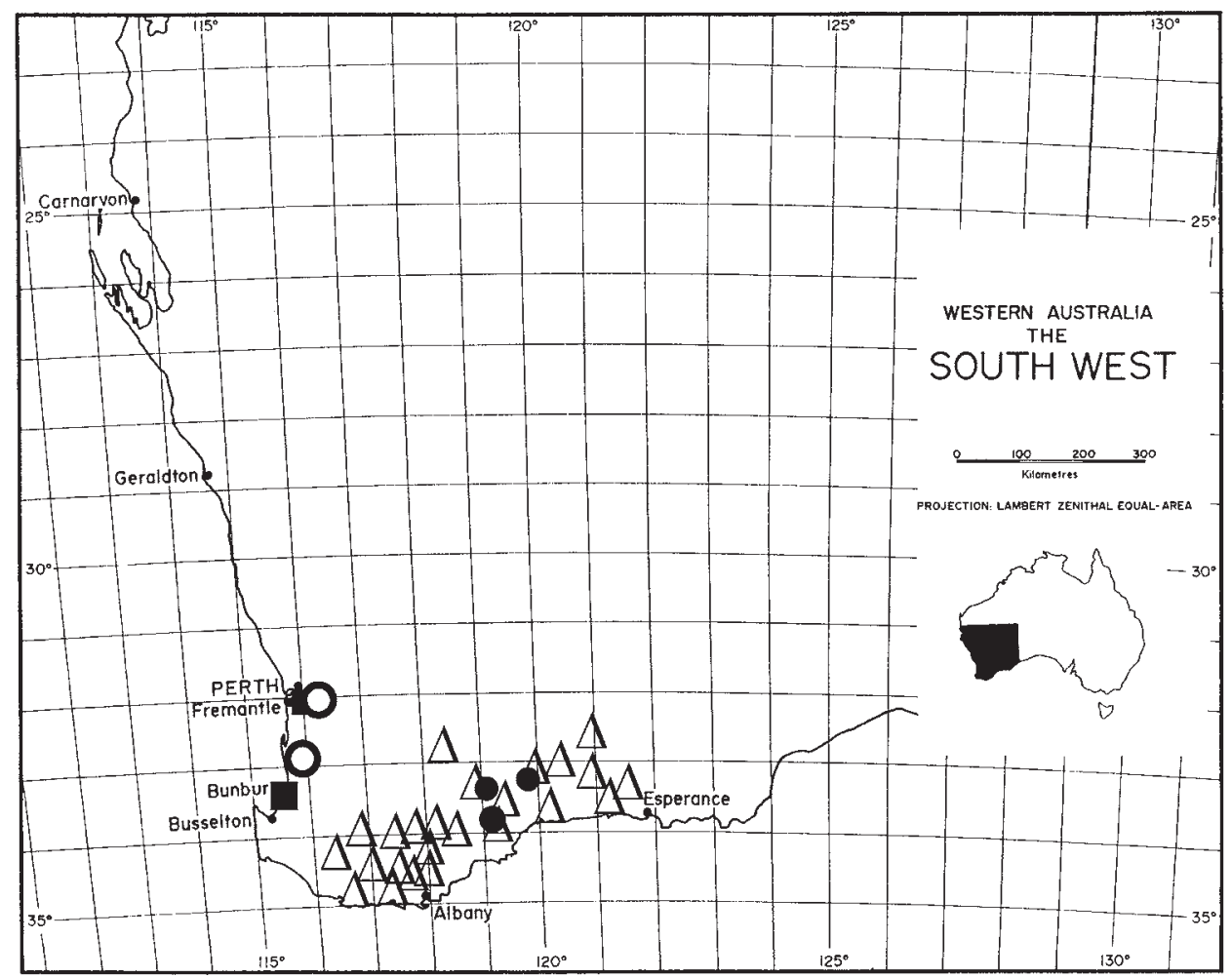

Fig. 2. Distribution of collections of Austrostipa subgenus Lobatae in Western Australia.

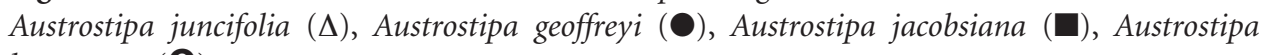
bronwenae $(\mathbf{O})$. 


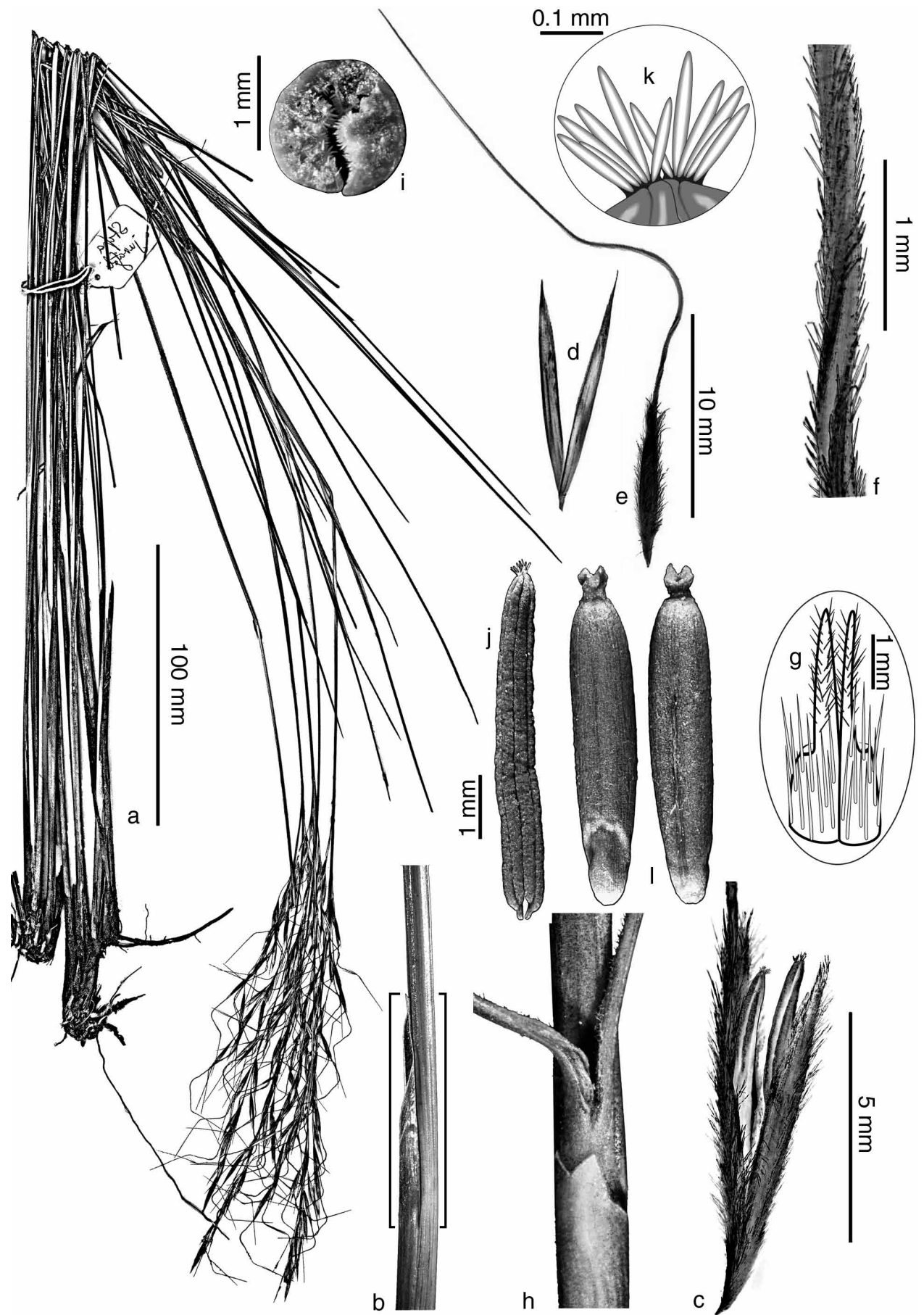

Fig. 3. Austrostipa juncifolia. a, whole plant from herbarium sheet; b, ligule (side view, delimited by brackets); c, floret with penicillate anthers exposed; $\mathbf{d}$, glumes; e, floret with awn; $\mathbf{f}$, column segment; g, lemma apex with long lobes (awn column removed); $\mathbf{h}$, glabrous involucel at base of panicle; $\mathbf{i}$, folded leaf section; $\mathbf{j}$, penicillate anther; $\mathbf{k}$, penicillata ( 6 atop each locule of anther); 1, caryopsis (embryo side left; hilum side right). Digital images prepared from: a Burgman 4310; b-k Royce 6036 and 1 McKeough 9. 
Selected specimens examined: Western Australia: 1 mile E of Kau Rock, 16 Oct 1970, T.E.H. Aplin 4068; Lake Kirk, SW of Norseman, 22 Oct 1985, D.J. Bedford 518, J. Powell \& J. Everett; Cape Riche, Cheyne Beach headland, $80 \mathrm{~km}$ E of Albany, site near car park lookout on headland, 7 Jan 2003, U. Bell 484; Along East Bank Road, Kalgan River, Albany, 21 Jan 2004, U. Bell 503; 4.1 km NW of Savages Road on Eld Road, reserve 32777, Oct 1984, M.A. Burgman 4310; Approximately 35 km NW of Salmon Gums, off Kumarl Lake King Road, 6 Nov 2007, G. Cockerton \& N. McQuoid LCH 15983; Gairdner River, Jerramungup, Aug 1939, C.A. Gardner s.n.; Ravensthorpe, Nov. 1944, C.A. Gardner s.n.; South Stirling, 11 Dec 1964, A.S. George 6494; Martin Creek, near Fitzgerald River, Fitzgerald River National Park, 7 Sep 1971, A.S. George 10939; 2 km S of Ranger Station, Fitzgerald River National Park, 29 Nov 1993, S.W.L. Jacobs 7017; margin of Quarderwardup Lake, Stirling Ranges, 19 Oct 1982, G.J. Keighery 5488; Kodjinup Nature Reserve, 21 Oct 1997, G.J. Keighery \& N. Gibson 2210; salt lake E of Salmon Gums, 23 Oct 2000, M.N. Lyons \& S.D. Lyons 3404; 1.7 km along East Kylie Road from Arthur River - Boyup Brook Road, Bokal, 28 Nov 2001, K. McKeough 9; 5 km NW of Ongerup, 24 Sep 1972, K.R. Newbey 3587; 5 km S of Peak Eleanora, Peak Charles National Park, 8 Nov 1979, K.R. Newbey 6341; In valley between quartzite ridges, $1.5 \mathrm{~km}$ E of Thumb Peak, 26 Sep 1997, F. Obbens 45/97; S side of river, lower King River, 29 Jan 1993, L.J. Pen 279; E of Cranbrook, towards Stirling Range, 26 Oct 1959, R.D. Royce 6036; Merivale Road just E of track into Myrup Fly In Estate Airstrip E of Fisheries Road, 18 Aug 2005, C.D. Turley \& R.M. Hoggart 208/805.

Conservation Status: this species is common within its range.

Affinities: A. juncifolia is the type species for the subgenus. It differs from A. geoffreyi in having smaller vegetative and floral dimensions (Table 1), glabrous style, and less extreme salt tolerance. Their erect habit, glabrous and juncus-like foliage, salt tolerance, long lemma lobes and long ligules distinguish these two species from all Western Australian Austrostipa species in other subgenera.

Austrostipa geoffreyi S.W.L.Jacobs \& J.Everett, Telopea 6: 585 (1996).

Type: Western Australia, Lake King, 3305'S, 119³3'E, 2 Dec 1993, S. W.L. Jacobs 7030 (holo: NSW293105; iso: PERTH 05198771).

Perennial grass, 90-180 cm tall. Leaf sheaths 8-14 mm wide at the base of the culm, 5-10 $\mathrm{mm}$ wide at the upper nodes, ribbed, glabrous or puberulous with hairs $0.1-0.3 \mathrm{~mm}$ long. Ligules $6-12 \mathrm{~mm}$, smoothly integrated with the sheath so there are no sheath lobes. Leaf blades 55-100 cm long, 1-2 mm wide; blade folded making an oval cross-section, abaxial surface unribbed, glabrous and smooth, adaxial surface strongly ribbed, pubescent with an even covering of erect hairs $0.03-0.6 \mathrm{~mm}$ long. Panicle 30-40 cm long, exserted, spreading, 3-5 cm wide, involucel of one or two glabrous bracts 1.5-2.5 mm long; lowest panicle internode 35-47 mm long, glabrous; shortest undivided branch 2-4 mm long, longest undivided branch 4-6 $\mathrm{mm}$ long; branches terete, mostly glabrous but with hairs near the axils, $60-95 \mathrm{~mm}$ long overall including glumes; pedicels likewise terete, mostly glabrous, sometimes with hairs near the axils, 3-13 mm long; spikelets 29-35 per node, 12-15 mm long. Glumes persistent, subequal, acuminate, glabrous, straw-coloured; lower glume 3-nerved, 12-15 mm long; upper glume 3-nerved, 12-16 mm long. Floret 9-12 mm long, without a neck, sericeous with white hairs at maturity, $1-1.5 \mathrm{~mm}$ long, increasing in length towards the apex. Lemma lobes 2, 2.5-3.0 mm long; coma 3-4 mm long; callus 2-3 mm long, sericeous with white hairs $0.1-1.0 \mathrm{~mm}$ long, tip weakly bent. Awn $50-80 \mathrm{~mm}$ long, $0.25-0.3 \mathrm{~mm}$ wide near the base; column 10-20 mm long, 5-10 $\mathrm{mm}$ to the first bend, scabrous, with hairs 


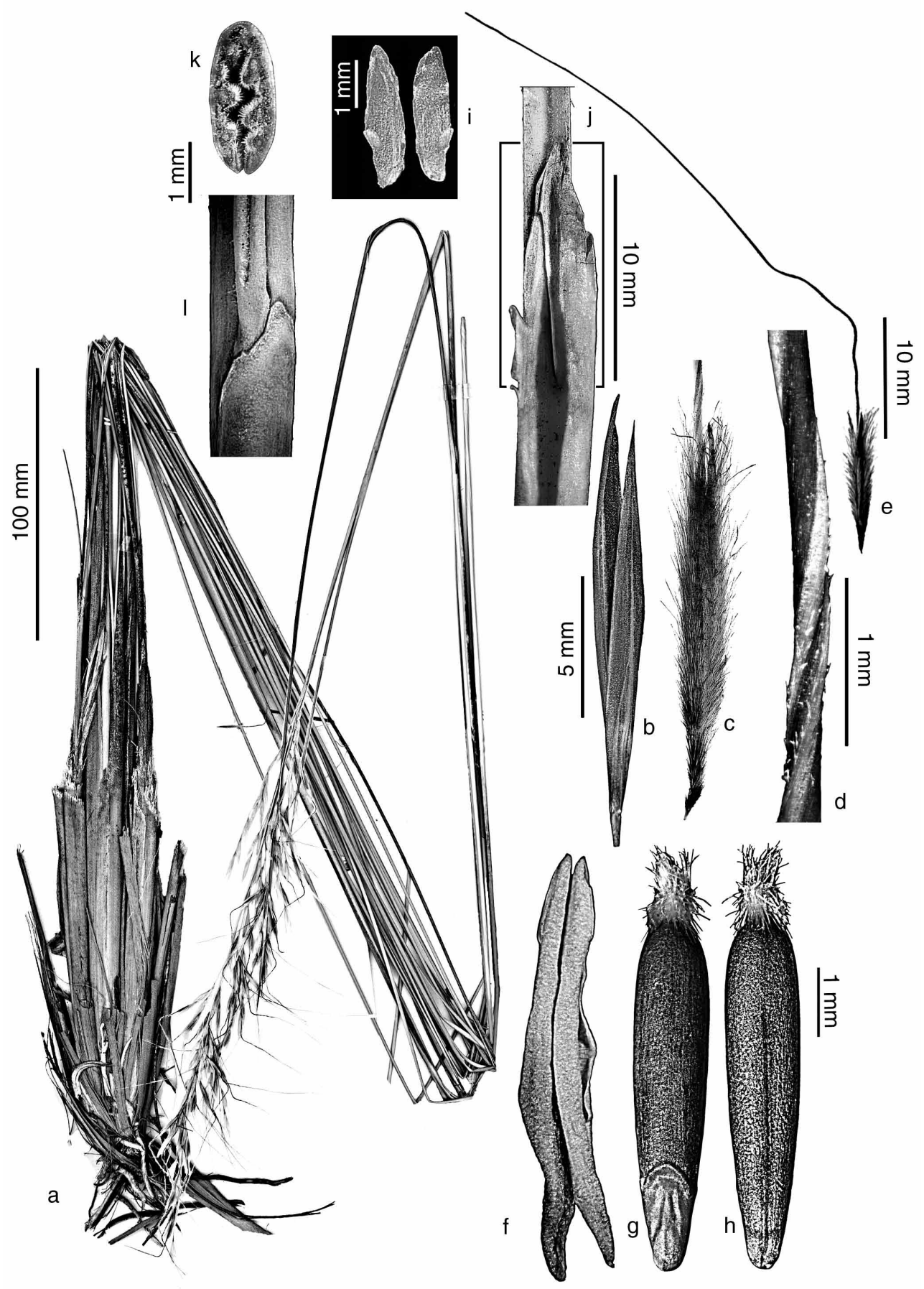

Fig. 4. Austrostipa geoffreyi. a, composite of whole plant from herbarium sheets; b, glumes; c, floret; $\mathbf{d}$, column section; e, floret with awn; f, non-penicillate anther; $\mathbf{g}$, caryopsis, embryo side; $\mathbf{h}$, caryopsis, hilum side; $\mathbf{i}$, abaxial lodicules; $\mathbf{j}$, ligule; $\mathbf{k}$, folded leaf section; $\mathbf{l}$, glabrous involucel at base of panicle. Digital images from: a [tussock], b-e, k George 10466; a [panicle], f Cochrane 4243; g-j, 1 Jacobs 7030. 
Table 1. Morphological differences between Western Australian species of Austrostipa subgenus Lobatae.

\section{Characters (dimensions in $\mathrm{mm}$ )}

Basal leaf sheath width

Upper leaf sheath width

Ligule margin

Ligule length

Leaf blade

Leaf blade width

Panicle length

Panicle width

Panicle involucel length

Panicle involucel hairs

Panicle involucel extent

Panicle axis and branch

indumentum

Panicle internode length

Maximum undivided branch length

Pedicel length

Spikelets per panicle node

Upper glume length

Upper glume nerves in lower part

Floret length

Lemma hair colour at maturity white

Lemma hair length

Lemma lobe length

Coma length

Callus length

Callus hair colour

Awn width near the base

Column length to the

first bend

Column indumentum

Paleal lodicule length

Anther length

Anther apex

Style indumentum

Habitat

Distribution (W.A. botanical districts)

$$
\begin{aligned}
& \text { jun } \\
& 7-9 \\
& 3-6 \\
& \text { ent } \\
& 2.5-8 \\
& \text { fold } \\
& 1-2 \\
& 270-3 \\
& 35-80 \\
& 0.5 \\
& \text { gla } \\
& \text { part } \\
& \text { gla } \\
& \text { 60-80 } \\
& 25-40 \\
& 0.5-2 \\
& 8-20 \\
& 9-10 \\
& 3 \\
& 6.5
\end{aligned}
$$

6.5-9$$
0.5-0.8
$$$$
1-2.5
$$$$
1.3-3
$$$$
1.1-1.5
$$$$
\text { white }
$$$$
0.2-0.25
$$$$
5-10
$$

scabrous

$1.5-2$

5-6 penicillate glabrous saline areas

Coolgardie, Jarrah Forest Avon Wheatbelt, Mallee, Esperance Plains

\section{Species}

jacobsiana bronwenae

$\begin{array}{ll}3-4 & 2-3 \\ 1-1.5 & 1.5-2 \\ \text { entire } & \text { laciniate } \\ 0.4-1 & 0-0.3 \\ \text { folded } & \text { rolled } \\ 0.5-0.8 & 0.5-1.2 \\ 100-200 & 250-300 \\ 10-20 & 30-40 \\ 0 & 0 \\ \text { glabrous } & 0.3-1.3 \\ \text { partial } & \text { complete } \\ \text { scabrous } & \text { scabrous } \\ & \\ 20-25 & 47-72 \\ 24-36 & 20-28 \\ 3-13 & 3-28 \\ 14-24 & 11-15 \\ 9-12 & 11-12 \\ 5 & 3\end{array}$

6-8 7-8

white white light or dark brown

$\begin{array}{lll}1-1.5 & 0.4-0.5 & 0.5-0.6\end{array}$

$\begin{array}{lll}2.5-3 & 0.4-0.8 & 0.3-1\end{array}$

3-4 $\quad 1.1-1.5 \quad 0.7-1.3$

$\begin{array}{lll}2-3 & 1.6-2.1 & 1.5-1.8\end{array}$

white white golden

$\begin{array}{lll}0.25-0.3 & 0.25-0.3 & 0.33-0.4 \\ 5-10 & 8-12 & 12-17\end{array}$

$\begin{array}{lll}\text { scabrous } & \text { scabrous } & \text { pubescent } \\ 1.5-2.5 & 1.3-2 & 0.8 \\ 4.3-5.5 & 3.2-3.3 & 4.2-5 \\ \text { not penicillate } & \text { not penicillate } & \text { penicillate } \\ \text { hirsute } & \text { glabrous } & \text { glabrous } \\ \text { salt lake margins non-saline } & \text { non-saline winter- } \\ & \text { calcareous soils } & \text { wet calcareous soils } \\ \text { Mallee } & \text { Swan Coastal } & \text { Swan Coastal Plain } \\ & \text { Plain } & \end{array}$


0.1-0.2 mm long; bristle triangular, no broader than column, paler than the column, scabrous with hairs $0.1-0.15 \mathrm{~mm}$ long. Palea equal to and almost completely enclosed by lemma, with glabrous margins, pubescent between the dorsal nerves. Lodicules 3 , membranous; abaxial lodicules acutely ovate, $1.0-4 \mathrm{~mm}$ long, $0.5-1 \mathrm{~mm}$ wide; paleal lodicule acuminate, 1.5-2.5 mm long, 0.2 mm wide. Anthers 2(3?), 4.3-5.5 mm long, not penicillate. Style densely hispid with hairs $0.5-0.8 \mathrm{~mm}$ long. Caryopsis $4-6 \mathrm{~mm}$ long, $1.0 \mathrm{~mm}$ wide; hilum 3.5-4.5 mm long; embryo 2-3 mm long. (Fig. 4)

Distribution and habitat: occurs in the Western Australian Mallee IBRA region (Fig. 2). Known only from Lake King, Lake Grace, and Lake Chinocup, growing on slightly elevated ground amongst samphires, or on the inner margin of fringing vegetation surrounding salt lakes.

Phenology: flowers October-November with fruit maturing in November-December.

Other specimens examined: Western Australia: [precise localities withheld for conservation reasons] Lake King, 11 Jun 1988, S.W.L. Jacobs 5854 \& P. Wilson; Lake King, 11 Nov 1970, A.S. George 10466; Lake King, 6 Nov 2002, J.A. Cochrane 4243; Lake Grace South, 20 Dec 1994, M. Graham 227.11; Lake Chinocup, 2 Nov 2006, T.D. Macfarlane 3926.

Conservation status: Department of Environment and Conservation (DEC) Conservation Codes for Western Australian Flora (Atkins 2008): Priority One.

Affinities: morphologically similar to A. juncifolia, growing within its geographic range, but a vegetatively larger (Table 1 ) and obviously more salt tolerant plant. Easily distinguished by its habitat, larger flowers in all measures, denser panicle, and unique, densely hispid style.

\section{Austrostipa jacobsiana A.R.Williams, sp. nov.}

A. juncifoliae affinis sed ligula et lemmatis lobis brevioribus, et habitatione dissimili differt.

Austrostipa juncifolia subsp. Southern River (B.J. Keighery 2160) WA Herbarium (1998+) FloraBase: the Western Australian Flora Version 2.5.9. (accessed 2008)

Type: Western Australia, Southern River, Perth, [precise locality withheld for conservation purposes], 14 Nov. 2003, A.R. Williams 881 (holo: PERTH 07770111; iso: NSW).

Perennial grass, $80-120 \mathrm{~cm}$ tall. Leaf sheaths 3-4 mm wide at the base, 1-1.5 mm wide at the top, visibly ribbed, puberulous between the ribs in the lower parts with hairs 0.03-0.06 mm long. Upper leaf sheath margin with hairs $0.01-0.02 \mathrm{~mm}$ long. Ligule obtuse, usually entire, membranous, $0.4-1 \mathrm{~mm}$ long. Auricular region glabrous, sheath lobes protruding above the ligule and continuous with it. Leaf blade $35-45 \mathrm{~cm}$ long, 0.5-0.8 mm wide; blade folded and swollen making a terete form, abaxial surface unribbed, glabrous and smooth, adaxial surface strongly ribbed, with an even covering of erect surface hairs 0.03-0.6 mm long. Panicle 10-20 cm long, exserted, contracted, 1-2 cm wide, partially subtended by a short glabrous involucel; lowest panicle internode 20-30 mm, scabrous, the hairs 0.06-0.1 mm long; shortest undivided branch 3-4 mm long, longest undivided branch 24-36 mm long; branches somewhat flattened, scabrous, 40-80 mm long overall including glumes; pedicels somewhat flattened 3-13 mm long, scabrous, the hairs $0.1-0.15 \mathrm{~mm}$ long; spikelets $14-24$ per node, 10-12 mm long. Glumes persistent, subequal, acuminate, glabrous, straw-coloured; 
lower glume 3-nerved, 10-12 mm long; upper glume 5-nerved, 9-12 mm long. Floret 6-8 mm long, without a neck, sericeous with white hairs $0.4-0.5 \mathrm{~mm}$ long that increase in length towards the apex. Lemma lobes 2, 0.4-0.8 mm long; coma 1.1-1.5 mm long; callus 1.6-2.1 mm long, sericeous with white hairs $0.6-0.7 \mathrm{~mm}$ long, tip weakly bent. Awn 38-49 $\mathrm{mm}$ long, $0.25-0.3 \mathrm{~mm}$ wide near the base, column $12-21 \mathrm{~mm}$ long, $8-12 \mathrm{~mm}$ to the first bend, scabrous, with hairs $0.1-0.3 \mathrm{~mm}$ long; bristle triangular, no broader than column, paler than the column, scabrous with hairs $0.1-0.15 \mathrm{~mm}$ long. Palea equal to and almost completely enclosed by lemma, with glabrous margins, pubescent between the dorsal nerves. Lodicules 3, membranous; abaxial lodicules acutely ovate, $1.1-1.5 \mathrm{~mm}$ long, $0.3 \mathrm{~mm}$ wide; paleal lodicule truncate, $1.3-2.0 \mathrm{~mm}$ long, $0.1 \mathrm{~mm}$ wide. Anthers 3, 3.2-3.3 mm long, not penicillate. Style glabrous. Caryopsis $4.5-5 \mathrm{~mm}$ long, $0.8-0.9 \mathrm{~mm}$ wide; hilum 3-4 mm long, embryo $1.0-1.1 \mathrm{~mm}$ long. (Fig. 5)

Distribution and habitat: occurs in the Swan Coastal Plain IBRA region of W.A. (Fig. 2). Grows in non-saline, white or grey sandy clay soil developed over Muchea Limestone formations. The suburban Perth site is a well-drained white sandy clay roadside in degraded Eucalyptus/Banksia woodland. Bunbury specimens grow in winter-wet grey sandy clay soil in Melaleuca mixed tall shrubland.

Phenology: flowers October-November with fruit maturing in November-December.

Etymology: named in honour of the late Surrey Jacobs, in recognition of his pioneering work on the phylogenetics and taxonomy of Austrostipa, his personal assistance with this work, and his long-time contribution to Australian botany, notably on grasses and aquatic plants from which several of my own earlier works greatly benefitted.

Other specimens examined: Western Australia: [localities withheld for conservation reasons]. 10 Dec 1995, B.J. Keighery 2160; 29 Dec 2003 U. Bell 500; 11 Dec 2005 G.J. \& B.J. Keighery 673.

Conservation Status: this taxon was assigned Priority One (DEC Conservation Codes for Western Australian Flora) under the phrase name Austrostipa juncifolia subsp. Southern River (B.J. Keighery 2160). It exists as just two suburban populations in areas that have both been well studied and collected. The large size of the plant and its durable culms with persistent infloresence glumes make it easy to distinguish from accompanying vegetation so it is unlikely to have been overlooked in other locations. The Bunbury collection was located within a small reserve, but is surrounded by urban development. The Perth collection was just outside the fenceline of a Bush Forever site, on a roadside that is graded each year to provide a fire break. The surrounding area is rapidly being developed so there is no guarantee of survival of this tiny population given the increasing use of off-road vehicles, dumping of rubbish, and arson. I believe there is a good case here for transplantation to, and/or seed collection and propagation in, a reserved area.

Affinities: clearly morphologically related to A. juncifolia and the much larger A. geoffreyi. Similar also to A. petraea (Vickery) S.W.L. Jacobs \& J. Everettt (endemic to the semi-arid Flinders Ranges region of South Australia) in its short ligule and scabrous panicle branches, but differs in habitat, lemma hair colour and anther size and penicillation. Most similar to A. bronwenae in size and habitat, but differing in having shorter sheath lobes, folded and shorter leaves, glabrous involucel, shorter and narrower panicle, 5-nerved upper glume, white lemma hairs, narrower awn column, longer paleal lodicule, and shorter, non-penicillate anthers (Table 1). 


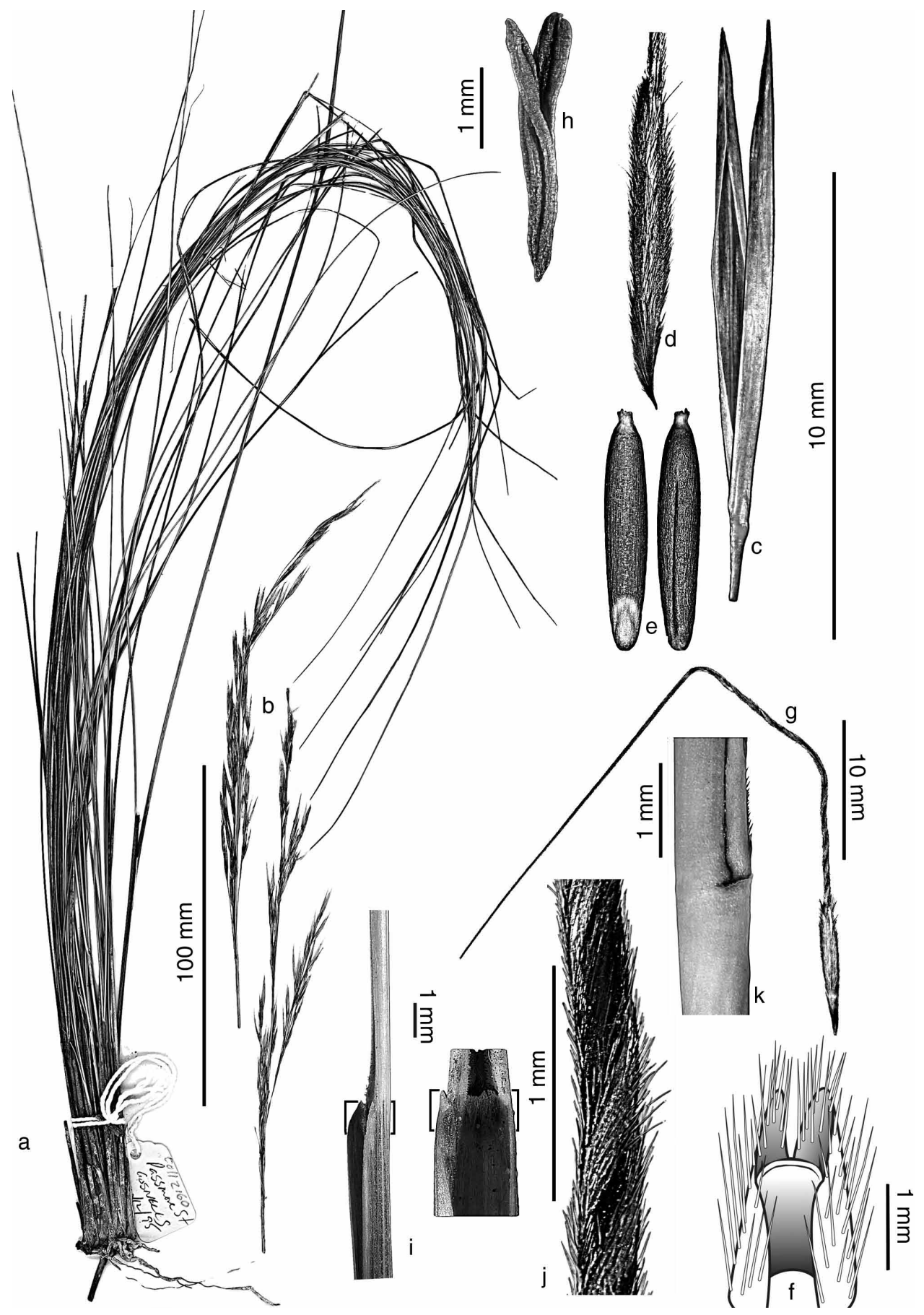

Fig. 5. Austrostipa jacobsiana. a, whole plant from herbarium sheet; b, panicles with empty glumes; c, glumes; d, floret without awn; e, caryopsis (embryo side left, hilum side right); $\mathbf{f}$, schematic of lobes at lemma apex with awn \& palea removed; $\mathbf{g}$, whole floret; $\mathbf{h}$, non-penicillate anther; $\mathbf{i}$, ligule (side view left, adaxial view right); $\mathbf{j}$, column segment; $\mathbf{k}$, involucel a glabrous ridge at base of panicle. Digital images from: a, b Keighery 2160; c-j Williams 881; k Bell 500. 


\section{Austrostipa bronwenae A.R.Williams, sp. nov.}

A. juncifoliae affinis sed panicula annulo pilulorum erectorum subtenta, ligula et lemmatis lobis brevioribus, pilis lemmatis fusco-atroaureis, et habitatione dissimili differt.

Austrostipa sp. Harvey (B.J. Keighery GWAL/1) WA Herbarium (1998+) FloraBase: the Western Australian Flora Version 2.5.9. (accessed 2009)

Type: Western Australia, Harvey, [precise locality witheld for conservation purposes], 8 Dec 2008, B.J. Keighery 2905 (holo: PERTH; iso: NSW, MEL, CANB).

Perennial grass, 90-150 cm tall. Leaf sheaths $2-3 \mathrm{~mm}$ wide at the base of the culm, $1-1.5 \mathrm{~mm}$ wide at the upper nodes, not ribbed, glabrous. Upper leaf sheaths glabrous, but lower sheath margins sometimes with hairs $0.1-0.3 \mathrm{~mm}$ long. Ligule $0.0-1.0(-2)$ $\mathrm{mm}$ long, either between asymmetrical sheath lobes (which can be 3-5 mm long), or if absent, then the sheath lobes do not join in the middle of the inside collar region. Auricular region unmarked, or sometimes marked with a darkened spot, glabrous, or with a few hairs $0.1-0.7 \mathrm{~mm}$ long. Leaf blade $35-45 \mathrm{~cm}$ long, $0.5-0.8 \mathrm{~mm}$ wide; terete, rolled or involute, abaxial surface not ribbed, glabrous and smooth, adaxial surface strongly ribbed, pubescent with an even covering of erect hairs $0.03-0.6 \mathrm{~mm}$ long. Panicle $25-30 \mathrm{~cm}$ long, exserted, contracted, $3-4 \mathrm{~cm}$ wide, subtended by an almost completely encircling involucel of hairs $0.3-1.3 \mathrm{~mm}$ long; lowest panicle internode 45-75 mm, scabrous, the hairs $0.03-0.06 \mathrm{~mm}$ long; shortest undivided branch 2-10 $\mathrm{mm}$ long, longest undivided branch $20-28 \mathrm{~mm}$ long; branches somewhat flattened with acutely angled edges, $80-120 \mathrm{~mm}$ long overall including glumes; pedicels likewise somewhat flattened, 3-13 mm long, scabrous on their acutely angled edges, the hairs $0.1-0.15 \mathrm{~mm}$ long; spikelets $11-15$ per node, $10-12 \mathrm{~mm}$ long. Glumes persistent, subequal, acuminate, glabrous, straw-coloured; lower glume 3-nerved, 11-13 mm long; upper glume 3-nerved, 11-12 mm long. Floret 7-8 mm long, without a neck, sericeous with dark golden brown hairs at maturity, $0.5-0.6 \mathrm{~mm}$ long, increasing in length towards the apex. Lemma lobes 2, $0.3-1.0 \mathrm{~mm}$ long; coma $0.7-1.3 \mathrm{~mm}$ long; callus $1.5-1.8 \mathrm{~mm}$ long, sericeous with golden hairs $0.4-1.0 \mathrm{~mm}$ long, tip weakly bent. Awn 42-55 mm long, 0.33-0.4 mm wide near the base, column 19-26 mm long, 11-17 mm to the first bend, scabrous, with hairs $0.2-0.4 \mathrm{~mm}$ long; bristle triangular, no broader than column, paler than the column, scabrous with hairs $0.07-0.15 \mathrm{~mm}$ long. Palea equal to and almost completely enclosed by lemma, with glabrous margins, pubescent between the dorsal nerves. Lodicules 3, membranous; abaxial lodicules acutely ovate, $1.0-1.2 \mathrm{~mm}$ long, $0.3 \mathrm{~mm}$ wide; paleal lodicule acuminate, $0.7-0.8 \mathrm{~mm}$ long, $0.2 \mathrm{~mm}$ wide. Anthers 3, 4.2-5.0 mm long, penicillate. Style glabrous. Caryopsis $4.1-4.6 \mathrm{~mm}$ long, $0.9 \mathrm{~mm}$ wide; hilum 2.7-3.6 mm long, embryo 0.9-1.0 mm long. (Fig. 6)

Distribution and habitat: occurs in the Swan Coastal Plain IBRA region of W.A. (Fig. 2). Grows in non-saline but seasonally wet grey-brown sandy loam soil containing nodules of Muchea Limestone, at the edge of a Gahnia trifida sedgeland with Eucalyptus decipiens. At the type site in 2003, plants were growing in three nodes over about 10ha, extending to the west and north of this population. However in 2008 only a single population of about 20 plants remained, growing within an area of about $200 \mathrm{~m}^{2}$. The dry years from 2003 to 2008 and extensive disturbance by pigs may have contributed to this decline. The site in suburban Perth is a similar habitat (dominated by Gahnia trifida and Melaleuca viminea) with just a few plants on one uncleared suburban lot and two similarly small clusters of plants on the adjacent lot. 

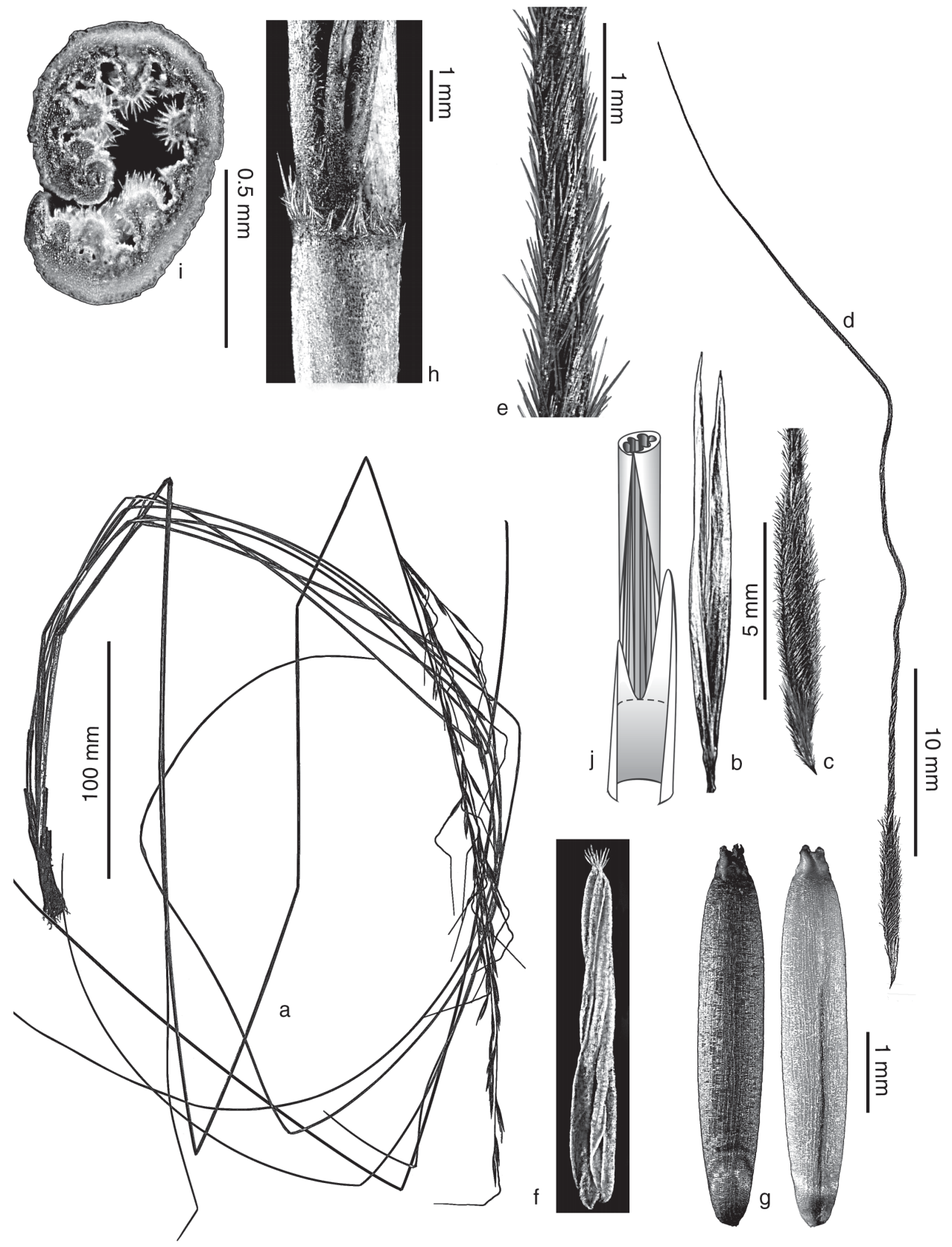

Fig. 6. Austrostipa bronwenae. a, whole plant from herbarium sheet; b, glumes; c, floret without awn; d, floret with awn; e, column section; f, penicillate anther; g, caryopsis (embryo side,left; hilum side right); $\mathbf{h}$, hairy involucel at base of panicle; $\mathbf{i}$, rolled leaf section; $\mathbf{j}$, asymmetrical leaf sheath lobes with no ligule. Digital images prepared from Keighery 2905. 
Phenology: flowers October-November with fruit maturing in November-December.

Etymology: named after Bronwen Keighery who found both new species in all three locations, assisted with habitat information from her long experience and in-depth studies of the Swan Coastal Plain, and collected fruiting material and type specimens.

Other specimens examined: Western Australia: [localities withheld for conservation reasons]. 23 Oct 2003, B.J. Keighery 2906, 2907; 18 Sep 2009, C. Tauss 3155, 3156.

Conservation status: this taxon has been collected in just two widely separated sites that each carries only small populations. The large size of the plant and its durable culms with persistent inflorescence glumes make it unlikely to have been overlooked in other surveys and other locations. In view of the dramatic reduction in population size in just 5 years at the type site, it clearly deserves urgent priority status for conservation.

Affinities: similar to A. juncifolia and A. geoffreyi in habit, but differing in having shorter lemma lobes and ligules and occupying quite a different habitat and geographical region. Similar to A. jacobsiana in habit, habitat and geographical region, but differing in having long sheath lobes, an involucel of hairs subtending the panicle, 3-nerved upper glume, dark golden-brown lemma hairs at maturity, broader awn column, and longer, penicillate anthers (Table 1).

\section{Acknowledgments}

The Western Australian Herbarium provided facilities and access to their collection throughout the course of this work. Dr Terry Macfarlane provided access to his DELTA dataset on the Australian Austrostipa, and provided oversight and funding for earlier phases of work on the genus in Western Australia. Bronwen Keighery assisted with information on Swan Coastal Plain habitats and with further collections of type material. Paul Wilson assisted with advice on nomenclature and Latin descriptions.

\section{References}

Atkins K (2008) Declared rare and priority flora list for Western Australia, 26 February 2008. (Department of Environment and Conservation: Kensington, Western Australia)

Everett J, Jacobs SWL \& Nairn L (2009) Austrostipa. Pp.15-62 in Flora of Australia, vol. 44A. Poaceae 2. (ABRS/CSIRO: Melbourne)

Gardner CA (1952) Flora of Western Australia, vol. 1(1). Gramineae. (Western Australian Government Printer: Perth)

Jacobs SWL \& Everett J (1996) Austrostipa, a new genus, and new names for Australasian species formerly included in Stipa (Gramineae). Telopea 6(4): 579-595.

Jacobs SWL, Everett J, Barkworth ME \& Hsiao C (2000) Relationships within the Stipoid Grasses (Gramineae). Pp. 75-82 in SWL Jacobs \& Everett J (eds) Grasses: Systematics and Evolution. (CSIRO Publishing: Melbourne)

Jacobs S, Bayer R, Everett J, Arriaga M, Barkworth M, Sabin-Badereau A, Torres A, Vázquez F \& Bagnall N, (2007) Systematics of the Tribe Stipeae (Gramineae) using molecular data. In: Columbus JT, Friar EA, Porter JM, Prince LM \& Simpson MG (eds) Monocots: Comparative Biology and Evolution-Poales. Aliso 23: 349-361. 
Keighery GJ \& Keighery BJ (1995) Muchea limestones: floristics. Report for ANCA National Reserves Network. (G. Keighery and B. Keighery: Perth, 8 pp.,1 map)

McCusker A (2007) Flora of Australia Glossary. (http://www.environment.gov.au/biodiversity/ abrs/online-resources/glossaries/vascular/index.html)

Simon BK (1993) A key to Australian grasses. (Queensland Dept. of Primary Industries: Brisbane) Simon BK \& Sharp D (2002) AusGrass: Grasses of Australia, Lucid Key on Compact Disk with illustrated Users Guide. (CSIRO Publishing: Melbourne)

Vegetti C \& Anton AM (2000) The Grass Inflorescence. Pp. 29-31 in Jacobs SWL \& Everett J (eds) Grasses: Systematics and Evolution, Proceedings of the Third International Symposium on Grass Systematics and Evolution (CSIRO Publishing: Melbourne)

Vickery JW, Jacobs SWL \& Everett J (1986) Taxonomic studies in Stipa (Poaceae) in Australia. Telopea 3(1): 1-23.

Manuscript received 18 December 2009, accepted 27 September 2010 